\title{
Marek Białokur*
}

Instytut Historii, Uniwersytet Opolski

\section{Rodzina Andrzejowskich i jej rola w zachowaniu polskiej tożsamości narodowej na Ukrainie na przykładzie aktywności oświatowo-wychowawczej Józefata Andrzejowskiego}

\section{The Andrzejowski family and their role in preserving the Polish national identity in Ukraine on the example of Józefat Andrzejowski's educational activity}

\begin{abstract}
The purpose of the article is to recall the history of Polish families in Eastern Europe, and strictly in Ukraine at the end of the $19^{\text {th }}$ and the beginning of the $20^{\text {th }}$ century. In a short article, however, it is difficult to tell their history in full. However, you can look at them from the perspective of individual stories, as in the case of Józefat Andrzejowski, who is active in economic and educational and educational grounds. He was born in 1849 in Kielce as the son of a November insurgent. After graduating from junior high school in Kielce, he went to Switzerland to study ceramics, where he was strongly influenced by Andrzej Towiański. In 1878 he moved to Kiev and founded a ceramics factory there. He got involved in the activities of the secret Society of Folk Education. In his factory he founded a school where secret lessons of Polish children and youth were held. In 1904 he was elected the president of the National Education Society, and from 1906 the chairman of the "Education" Society. In 1913 he was arrested, and a year later sent to Astrakhan for three years, where he worked for Polish deportees as part of the Society for Assistance to War Victims. In 1917 he returned to Kiev and was
\end{abstract}

* mbialokur@uni.opole.pl, ORCID: 0000-0002-8475-033X, Białokur, M. (2019). Rodzina Andrzejowskich i ich rola w zachowaniu polskiej tożsamości narodowej na Ukrainie na przykładzie aktywności oświatowo-wychowawczej Józefata Andrzejowskiego. Annales Collegii Nobilium Opolienses, 8, s. 93-110. 
elected president of the Polish Motherland and head of the education department of the Polish Executive Committee in Russia. During the Polish-Bolshevik war, he was wanted by the Soviet authorities. In October 1921 he came to independent Poland. Thanks to Andrzejowski and other Polish activists, over 100 children were rescued and removed from Kiev. In the Second Polish Republic he became involved in social activities. Andrzejowski was, among others, a treasurer and a member of the board of the Polish Red Cross in Warsaw and a member of the board of the Towarzystwo Pomocy Dzieciom i Młodzieży z Kresów. Józefat Andrzejowski, whose history is explained by the article, died in Warsaw in 1939. His many years of educational activity indicate that his real Polish family in the East were thousands of Polish children who created the conditions for learning.

Keywords: Józefat Andrzejowski, Poles in Kiev, educational activities

Dzieje polskich rodzin na Wschodzie to temat, którego podjęcie jest nie tylko wyzwaniem, ale przede wszystkim obowiązkiem współczesnej polskiej historiografii. Naznaczone z jednej strony zsyłkami, katorgą, cierpieniem, śmiercią setek tysięcy niewinny rodaków, z drugiej strony stanowią dowód niezwykłej determinacji, odwagi, religijności i nieustannej miłości Polaków do Ojczyzny, która jednak nie zawsze była skłonna upomnieć się o swoje dzieci. W wielowiekowej historii polskiej obecności na Wschodzie z całą pewnością wymiar szczególny miały wydarzenia epoki nowożytnej. Rywalizacja o wpływy na Litwie, Białorusi czy Ukrainie, wojny z Moskwą, wreszcie zapoczątkowana w XVIII stuleciu ekspansja Rosji na tereny należące do Rzeczypospolitej to prawdziwe kamienie milowe ojczystej historii, z których pomimo wielu klęsk Polacy potrafili wielokrotnie wychodzić obronną ręką. Dramat rozpoczął się z końcem wieku świateł, kiedy to na okres blisko dwóch wieków, z zaledwie krótkimi przerwami, naród polski stracił swą suwerenność głównie za sprawą rosnącego w siłę wschodniego sąsiada. Pokonani militarnie i nieustannie upokarzani zarówno w carskiej, jak i bolszewickiej Rosji zdołali Polacy zachować jednak własną tożsamość. Współcześnie, korzystając z przemian dokonujących się w byłych republikach Związku Sowieckiego, cienką strużką przyjeżdżają do Polski bądź też podejmują wymagający wielu wyrzeczeń trud organizowania polskiego życia społeczno-kulturalnego i gospodarczo-politycznego na Wschodzie, skąd w wielu wypadkach trudno byłoby im już dzisiaj wyjechać i rozpoczynać życie na nowo w niepodległej Polsce. Obserwując ten proces, powinniśmy uświadamiać sobie, że za każdą z tych osób kryje się często niezwykła rodzinna historia. Opowiadana z pokolenia na pokole- 
nie, utrwalona na obrazach lub fotografiach, czy też zapisana na kartach licznych wspomnień i pamiętników stanowi dla współczesnego historyka materiał bezcenny, będący niezaprzeczalnym dowodem na siłę i znaczenie rodzinnych więzów. W każdej polskiej rodzinie można bez trudu wskazać jednostki, które własną pracą, postawą, a nieraz i niezwykłym szczęściem potrafiły zapisać się w historii w sposób szczególny. Dzięki temu zarówno ich biografie, jak i historia reprezentowanych przez nich rodzin zapisały się w dziejach narodu polskiego w sposób szczególny i godny upamiętnienia. I właśnie jedną z takich postaci, której przez lata dane było żyć, pracować i działać na Ukrainie, głównie na gruncie gospodarczym i oświatowo-wychowawczym, był Józefat Andrzejowski - bohater niniejszego wystąpienia, człowiek którego już za życia honorowano w sposób szczególny.

Józefat Andrzejowski urodził się w 1849 roku w Kielcach w rodzinie o bogatej patriotycznej tradycji. Jego ojciec Antoni Andrzejowski (1807-1883) był absolwentem Wydziału Medycznego Uniwersytetu Jagiellońskiego. W okresie Powstania Listopadowego walczył w armii Królestwa Polskiego, odnosząc rany w bitwie pod Ostrołęką. Następnie jako ceniony lekarz pracował w szpitalu oficerskim w Warszawie. Za swoją służbę i wykazaną odwagę w trakcie wojny polsko-rosyjskiej odznaczony został orderem Virtuti Militari. Począwszy od 1844 roku zajmował przez wiele lat stanowisko lekarza powiatu kieleckiego. W uznaniu zasług wybrany został w 1862 roku do Rady Miejskiej Kielc. W okresie Powstania Styczniowego Antoni Andrzejowski włączył się aktywnie w pomoc powstańcom. Jako lekarz przenosił rannych insurgentów z więzienia do szpitala, czym w wielu wypadkach ratował im życie. Przedzierał się także do obozów powstańczych, by udzielać rannym niezbędnej pomocy medycznej. Jego wstawiennictwo było ponadto bezcenne przy uwalnianiu powstańców przed zesłaniem na Sybir. Ta patriotyczna działalność Andrzejowskiego nie mogła ujść uwadze władz carskich, które w 1865 roku aresztowały go wraz grupą innych Polaków pomagających byłym powstańcom. Z więźnia na warszawskim Pawiaku wyszedł dzięki wstawiennictwu i sowitym łapówkom oczyszczony z zarzutów. Resztę swojego bogatego życia spędził w Kielcach, będąc cenionym lekarzem i społecznikiem. Jego pogrzeb w sierpniu 1883 roku stał się wielką patriotyczną manifestacją. O matce Józefata Aleksandrze Andrzejowskiej z Wysokich (1816-1890) wiemy niestety znacznie mniej, gdyż tak jak większość ówczesnych kobiet zajmowała się głównie prowadzeniem domu. Z zachowanych dokumentów wynika, że była córką Tomasza 
Wysockiego, rektora liceum w Krakowie. Należy jednak pamiętać, że tak jak w przypadku wielu innych Polek, to właśnie ich stałej obecności w domu dzieci zawdzięczały nie tylko bardzo dobrą opiekę, ale także patriotyczne wychowanie kształtowane przez wspólną lekturę, rozmowy i kultywowanie rodzinnej oraz narodowej tradycji. Małżeństwo Antoniego i Aleksandry Andrzejowskich tak charakteryzował autor artykuły, który ukazał się na łamach „Gazety Lekarskiej” w 1897 roku: „byli przesiąknięci do głębi zasadami chrześcijańskimi i miłością bliźniego w najszerszym tego słowa znaczeniu, byli miłośnikami wszystkiego, co dobre i wzniosłe, jeden tylko mieli cel przed sobą: wprowadzać te zasady w czyn na wszelkim polu, jakie przed nimi stawiało życie. To też skromny a gościnny dom ich był przytułkiem i oparciem dla wielu”"

Małżeństwo Andrzejowskich miało dziewięcioro dzieci. Obok Józefata byli to m.in. Jan Antoni starszy od niego o dziesięć lat. Podobnie jak ojciec lekarz z wykształcenia, który przejął także po nim stanowisko lekarza powiatu kieleckiego. I choć brak bliższych informacji o Janie Antonim, to można założyć, że również uczestniczył w działalności konspiracyjnej. Świadczyć o tym może choćby zniekształcony nos, który zdaniem autorów pracy o zasłużonych kielczanach pochowanych na Starym Cmentarzu w tym mieście mógł być dowodem, iż odniósł rany podczas Powstania Styczniowego ${ }^{2}$. Kolejny z braci Józefata Konrad, za wiedzą i przyzwoleniem ojca, był dowódcą oddziału powstańczego podczas insurekcji lat 1863-1864. Jego z kolei wspierał Lucjan Andrzejowski, który w chwili wybuchu powstania był uczniem szóstej klasy kieleckiego gimnazjum. Jak podaje rodzinna tradycja, wykorzystując młody wiek, przedzierał się w okolice stacjonowania oddziałów rosyjskich i dzięki temu dostarczał starszemu bratu informacji o potencjale i ruchach wojsk carskich. Kolejny z braci Józefata Feliks aktywnie działał wraz z nim w polskim środowisku na Ukrainie.

Przechodząc już bezpośrednio do biografii Józefata, należy na wstępie zauważyć, że tak bogata historia rodzinna nie mogła pozostać bez wpływu na przebieg jego życiowej drogi. I tak w 1868 roku ukończył kieleckie gimnazjum, po którym zdecydował się na kontynuowanie nauki

1 Cyt. za: Przemówienie prezesa Józefa Świeżyńskiego, [w:] Pamiątka jubileuszu Józefata Andrzejowskiego uczczonego obchodem uroczystym 16 czerwca 1929, Warszawa [b.d.w.], s. 18.

2 http://powstaniec1863.zsi.kielce.pl/index.php?id=m10 [dostęp: 11.12.2019]. 
w Szwajcarii. Tam w Zurychu, jak określono to w jego życiorysie, podjął praktyczne studia ceramiczne ${ }^{3}$. Jak pokazały kolejne lata, to jednak nie studia, ale fakt, iż właśnie tam poznał Andrzeja Towiańskiego - filozofa, mistyka i religijnego przywódcę, pod którego wpływem pozostawali m.in. Adam Mickiewicz, Juliusz Słowacki czy Seweryn Goszczyński, odegrał w życiu Andrzejowskiego decydujące znaczenie. Towiański, jak po latach wspominał Andrzejowski, rozpalił w nim żądzę pracy dla dobra Polski w miłości dla Boga i ludzi słowami: „Idź w życie z wiarą i ufnością w Boga, z miłością do ludzi, idź w rzeszę robotniczą, w lud, umoralniaj, podnoś, służ, buduj dusze, a przez te dusze przyszłość Polski”4.

Zdobytą podczas zagranicznych studiów wiedzę i doświadczenie wykorzystał do założenia i sprawnego zorganizowania cegielni i warsztatów ceramicznych pod Krakowem, gdzie osiadł po powrocie ze Szwajcarii. W realizacji przedsięwzięcia wsparł Andrzejowskiego m.in. Galicyjski Bank Parcelacji i Budowy w Łagiewnikach, który był początkowo współudziałowcem inwestycji. W ciągu krótkiego czasu Andrzejowski awansował na kierownika całego przedsięwzięcia. Dzięki zaangażowaniu i pracowitości oraz ideałom, które zaszczepił w nim Towiański, zyskał ogromny wpływ na własnych pracowników.

W 1878 roku Andrzejowski nieoczekiwanie zlikwidował swoje zakłady pod Krakowem i kierowany, jak po latach wspominali jego uczniowie i współpracownicy, wewnętrzną siłą przeniósł się do Kijowa ${ }^{5}$, aby tam szerzyć ideę posłannictwa Polski ${ }^{6}$. U podłoża tej decyzji legło przeświadczenie, że Kresy Wschodnie, a w szczególności Ukraina, to obszar, gdzie polskość była poważnie zagrożona, a „...carat, prowadził politykę

3 J. Stemler, Życiorys, [w:] Pamiątka jubileuszu Józefata Andrzejowskiego uczczonego obchodem uroczystym 16 czerwca 1929 roku, Warszawa 1930, s. 7.

4 Józefatowi Andrzejowskiemu w hołdzie, „Myśl Narodowa” (dalej: „MN”), nr 25 z 16 VI 1929, s. 394.

5 Zagadnieniu osiedlania się przez Polaków na terenie guberni kijowskiej w II połowie XIX w. dużo miejsca poświęcił Joachim Bartoszewicz w rozprawie $\mathrm{Na}$ Rusi polski stan posiadania wydanej w Kijowie w 1912 r. Zob. także: W. Wielhorski, Ziemie ukrainne Rzeczypospolitej. Zarys dziejów, „Pamiętnik Kijowski” [dalej: „PK”], t. I, Londyn 1959, s. 86-90; P. Eberhardt, Polska ludność kresowa. Rodowód, liczebność, rozmieszczenie, Warszawa 1998, s. 170-172.

6 Biblioteka Polskiej Akademii Umiejętności i Polskiej Akademii Nauk w Krakowie (dalej B PAU i PAN w Krakowie), Teki Zielińskiego: Jan Kornecki, Pamiętniki, mf. 1476, k. 206. 
imperialną"”. Pobyt w Kijowie rozpoczął od zakupu pustego placu na Padole przy ul. Kiryłowskiej, gdzie po przezwyciężeniu najrozmaitszych trudności założył własną fabrykę ceramiczną z wyrobami kaflowymi ${ }^{8}$. $\mathrm{W}$ realizacji przedsięwzięcia dopomógł mu kijowski architekt Walery Kulikowski wraz z małżonką. Fabryka w zamierzeniach jej twórcy od samego początku miała stanowić oparcie dla pracy oświatowo-społecznej. Służąc narodowi polskiemu, środki, które gromadził dzięki fabryce, przeznaczał na działalność, którą pragnął objąć niemal cały obszar Rusi. Jednym z pierwszych efektów tej pracy było założenie w 1881 r. tajnej szkoły, w której zajęcia prowadzone były na terenie zakładu ceramicznego. Tym samym stał się Andrzejowski jednym z inicjatorów polskiego ruchu oświatowego w guberni kijowskiej. Zdaniem Daniela Beauvois działania Andrzejowskiego były skierowane głównie do dzieci zdeklasowanej szlachty, powszechnie uważanej za polską, stanowiąc elementem akcji repolonizacyjnej ${ }^{9}$. W tym kontekście francuski historyk, od lata zajmujący się historią polskiej obecności na Ukrainie, podważył m.in. wnioski Leszka Zasztowta zawarte w artykule z 1990 roku pt.: Polskie szkólki ludowe na Ukrainie w latach 1905-1914. Nam jednak pamiętając o ponadnarodowym charakterze nauki Towiańskiego, której Andrzejowski był gorącym zwolennikiem, wypada zwrócić uwagę, iż nie wydaje się do końca słuszne, a tym bardziej uprawomocnione przysłowiowe wrzucanie go do jednego worka z innymi założycielami szkół ludowych. I jeśli nawet, o co trudno mieć z resztą do niego pretensje, kultywował narodowe - polskie elementy w edukacji i wychowaniu, to w jak w takim układzie traktować wszystko to, czego np. polska młodzież uczyła się, wyjeżdżając na zachodnie uniwersytety, gdzie nikt nie zawracał sobie głowy podważaniem wyjątkowej roli niemieckiej nauki w świecie czy też kolonialnych aspiracji takich państw jak Anglia czy Francja. Dlate-

7 D. Beauvois, Trójkąt ukraiński. Szlachta, carat i lud na Wołyniu, Podolu i Kijowszczyźnie 1793-1914, Lublin 2005, s. 736.

8 Biblioteka Narodowa (dalej: BN), D. Szarzyński-Sęp, Polskie Towarzystwo Oświaty Ludowej na Rusi. Szkice i przyczynki do dziejów oświaty polskiej na Rusi w latach 1870-1920, akc. 8747, k. 80. (W kierowaniu fabryką przez kolejne lata Andrzejowskiego często wspierał brat Feliks, który także przybył do Kijowa).

9 D. Beauvois, Rosyjsko-polska wojna o oświatę na terenie Ukrainy (1863-1914), [w:] Europa Nie prowincjonalna. Przemiany na ziemiach wschodnich dawnej Rzeczypospolitej. Białoruś, Litwa, Ukraina, wschodnie pogranicze III Rzeczypospolitej Polskiej w latach 1772-1999, red. K. Jasiewicz, Warszawa 1999, s. 422. 
go też nie powinno się, upraszczając problem, odbierać jako przejawów polskiego nacjonalizmu oświatowo-wychowawczych działań Andrzejowskiego i bez zbędnych emocji czytać to, co na temat jego aktywności pisał m.in. Jan Kornecki ${ }^{10}$. Ten wybitny działacz oświatowy związany z obozem narodowo-demokratycznym poznał osobiście Andrzejowskiego, i zapewne dzięki temu w swoich pamiętnikach pisał o jego pracy w Kijowie, co następuje: „...rozpalał umysły i serca ludzkie dla umiłowanej przez siebie sprawy. Kupował elementarze i książki polskie i rozwoził je po całej Rusi, zachęcając miejscowych ludzi po miasteczkach i dworach do pracy oświatowej. Wychował sobie współpracowników takich jak szewc kijowski Budnicki, którzy narażali się na wielkie niebezpieczeństwo, jeżdżąc w charakterze emisariuszy Andrzejowskiego po kraju na długo przed rokiem 1905"11.

W opracowaniach dotyczących polskiej oświaty na Ukrainie Józefat Andrzejowski często wymieniany jest jako nestor tej działalności wraz z Leonardem Janowskim. Dla Stanisława Zielińskiego, jednego z założycieli Polonii - studenckiego stowarzyszenia założonego w Kijowie w 1901 roku $^{12}$ - a następnie przez szereg lat jednego $\mathrm{z}$ kierowników pracy narodowo-demokratycznej na Rusi, obaj wymienieni odegrali kluczową rolę w dziele organizowania oświaty polskiej. „Łożą na to pieniądze - pisał Zieliński - częściowo własne, częściowo zbierane od ludzi zaufanych. Opłacają nauczycielki, dostarczają podręczników i programów, utrzymują stosunki z klerem katolickim, aby nauczanie odbywało się zgodnie z zasadami Kościoła. Nie uczą sami, lecz bacznie śledzą przebieg nauczania, obecni podczas egzaminów, stale obcują z dziećmi, kontrolują rozwój umysłowy i rozwój charakterów. (...) Nie wszyscy się z nimi zgadzają, ale wszyscy szanują"13. W ocenie Zielińskiego zarówno Andrze-

10 Podstawowe informacje biograficzne na temat Korneckiego zob.: Kto byt kim w Drugiej Rzeczypospolitej, red. J.M. Majchrowski, Warszawa 1994, s. 323-324. Przed kilkoma laty wydana została także naukowa biografia poświęcona Korneckiemu: M.J. Żmichrowska, Jan Kornecki (1884-1967). Działalność oświatowa, społeczna, polityczna, Warszawa 1996.

11 B PAU i PAN w Krakowie, J. Kornecki, Pamiętniki, k. 206.

12 Więcej informacji na temat „Polonii” zob.: Biblioteka Zakładu Narodowego im. Ossolińskich we Wrocławiu (dalej Ossol.), S. Zieliński, Liga Narodowa na Rusi 1890-1920. Fragmenty historii pracy polskiej na kresach południowo-wschodnich, rkps 13202/II, k. 6-11.

13 Oświata polska na Rusi: S. Zieliński, Przedmowa do pracy Jana Korneckiego 
jowski, jak i Janowski starali się w swojej pracy unikać walk partyjnych i politycznych polemik, a narodowy charakter oświaty wzmacniali nie poprzez zwalczanie przeciwnych prądów, lecz własną ofiarną działalnością ${ }^{14}$.

Przełom XIX i XX wieku przyniósł na Rusi, a w szczególności w Kijowie, intensyfikację działań organizacyjnych, wzrost świadomości narodowej oraz powstanie nowoczesnych polskich nurtów politycznych, którą Daniel Bauvois określił mianem przebudzenia ${ }^{15}$. Pod wpływem wytwarzającej się atmosfery oraz wyniesionych z rodzinnego domu wartości, wspomnianego już wpływu Andrzeja Towiańskiego oraz własnej oceny sytuacji Józefat Andrzejowski postanowił zaangażować się w działalność założonej na Rusi z końcem XIX wieku tajnej Ligi Narodowej ${ }^{16}$. Jego wydatna pomoc przyczyniła się także do powstania „Polonii” ${ }^{17}$, będącej pierwszą tajną polską organizacją skupiającą młodzież akademicką o poglądach narodowo-demokratycznych w Kijowie, której był wieloletnim patronem, pełniąc funkcję prezesa Koła Seniorów ${ }^{18}$. Nazwisko Andrzejowskiego odnajdujemy ponadto w gronie twórców „Zrzeszenia”, organizacji powołanej z myślą o zorganizowaniu starszego pokolenia polskiego społeczeństwa kresowego, która miała mieć bezpartyjne oblicze, skupiając głównie przedstawicieli inteligencji miejskiej i wiejskiej ${ }^{19}$.

Sukcesy na niwie pracy społeczno-oświatowej Andrzejowski opłacał świadomie rezygnacją z życia prywatnego. Pomimo sporych dochodów, jakie osiągał, żył bardzo skromnie, wręcz ascetycznie. Wpływ na to miało przede wszystkim wywiązywanie się z przyjętych zobowiązań i świadomy wybór drogi życiowej. Znaczną część dochodów fabrycznych, podobnie jak środki uzyskane dzięki publicznej ofiarności, do której pobu-

„Oświata polska na Rusi w czasie Wielkiej Wojny Światowej”, „PK”, t. I, Londyn 1959, s. 193-194.

14 Tamże, s. 195.

15 D. Beauvois, Rosyjsko-polska wojna o oświatę..., s. 416.

16 S. Kozicki, Historia Ligi Narodowej. (Okres 1887-1907), Londyn 1964, s. 151. Zob. także B. Olizar, Liga Narodowa, „PK”, t. III, Londyn 1966, s. 168-172.

17 W.K., Wierzejewski, Fragmenty $z$ dziejów polskiej młodzieży akademickiej w Kijowie 1834-1920, Warszawa 1939, s. 91-92.

18 Ossol., K. Skrzyński, Wspomnienia z lat 1891-1917, rkps 15585/II, k. 71. Zob. także: T. Wolsza, Narodowa Demokracja wobec chłopów w latach 1887-1914. Programy, polityka, działalność, Warszawa 1992, s. 246-247.

19 S. Kozicki, Historia Ligi..., s. 150. 
dzenia w znacznym stopniu sam się przyczynił, regularnie przekazywał na szkoły uczące polskie dzieci. W tym miejscu warto odnotować, że na początku XX wieku kijowska fabryka ceramiki należąca do Andrzejowskiego zatrudniała blisko 200 robotników i przynosiła wcale nie mały dochód, który trudno jest jednak dzisiaj dokładnie oszacować ${ }^{20}$.

Poświęcenie i ofiarność Andrzejowskiego na polu pracy oświatowej, zostały docenione przez polską społeczność na Rusi. W 1904 roku podczas zakonspirowanego spotkania działaczy polskich z niemal całej Rusi, w domu Henryka Zdanowskiego, powołana została tajna organizacja pn. Towarzystwo Oświaty Narodowej, której prezesem jednogłośnie wybrano Andrzejowskiego. Po legalizacji statutu Towarzystwa „Oświata” w 1906 roku Andrzejowski został jego przewodniczącym. Krótki, zaledwie trzyletni okres legalnej działalności „Oświaty”, nie pozwolił mu jednak na stworzenie solidnych fundamentów dla polskich instytucji oświatowych na Ukrainie. Zamknięcie Towarzystwa „Oświata” w 1908 roku było równoznaczne ze zwiększeniem represji władz rosyjskich wobec Polaków, zmuszając tym samym działaczy polskich do pracy konspiracyjnej ${ }^{21}$. Jak pisał cytowany już Beauvois: „Historia szkolnictwa polskiego na Ukrainie w latach poprzedzających I wojnę światową charakteryzuje się taką samą stagnacją, jak za panowania Aleksandra III”22. I jeśli nawet jest w tej ocenie nieco przesady to generalnie trafnie oddaje klimat, w jakim przyszło działacz nie tylko Polakom, ale także Ukraińcom, Tatarom czy Żydom.

Postać Józefata Andrzejowskiego odnajdujemy także w gronie założycieli kijowskiego Polskiego Towarzystwa Gimnastycznego, wzorowanego na galicyjskim Sokole, które młodzież szybko ochrzciła mianem „Patagonia". W tworzeniu Towarzystwa aktywnie wspierał go brat Feliks, który był m.in. pomysłodawcą utworzenia chóru pod nazwą „Lutnia”. Z opublikowanej na łamach „Pamiętnika Kijowskiego” przeszło czterdzieści lat temu relacji wspomnieniowej syna Józefata Andrzejowskiego Zygmunta wynika, że „Patagonia” była przysłowiowym strzałem w dziesiątkę. Pod

20 Biogram Józefata Andrzejowskiego zob.: „PK” t. II, Londyn 1963, s. 78-79 .

21 Zagadnienie to szerzej omawiam w artykule: Powstanie i pierwsze lata działalności Towarzystwa Oświaty Narodowej na Rusi (1904-1909), [w:] Dzieje kształtowania się polskich instytucji oświatowych, red. A. Mierzwa, Piotrków Trybunalski 2002, s. 233-246. Zob. także: T. Wolsza, Towarzystwo Oświaty Narodowej (1899-1905), „Kwartalnik Historyczny” [dalej: „KH”], R. XCIV, 2 (1987), s. 94.

22 D. Beauvois, Rosyjsko-polska wojna o oświatę..., s. 429. 
hasłem $w$ zdrowym ciele $z$ drowy duch, Towarzystwo prowadziło różnorodną działalność, w której miejsce priorytetowe zajmowało wychowanie fizyczne. „Patagonia” posiadała ponadto sekcje wioślarską, kolarską, wycieczek pieszych, szermierki, a w zimie własną ślizgawkę. Dzięki takim atrakcjom lokal „Patagonii” tętnił życiem. „Wkrótce też okazało się, jak dalece szczęśliwą inicjatywę powzięto zakładając Towarzystwo i jak trafną nazwę wybrano. Gimnastyka i sport pociągały młodzież i to zdecydowało o rozroście Towarzystwa. Tu promieniowała polskość. Przychodzili tacy, którzy źle mówili po polsku, a nawet tacy, którzy wcale nie mówili i byli bardzo bliscy wynarodowienia się"23.

W tym czasie aktywność Andrzejowskiego przejawiała się również na polu działalności społeczno-religijnej. Jego nazwisko figuruje na liście członków komitetu budowy kijowskiego kościoła rzymsko-katolickiego, pod wezwaniem św. Mikołaja ${ }^{24}$. W 1913 roku na fali wzmożonych działań żandarmerii kijowskiej Andrzejowski został aresztowany, podczas tajnego spotkania, wraz z grupą polskich działaczy. W jego następstwie dwa miesiące spędził w kijowskim więzieniu na Łukjanówce. Represje za działalność oświatową spadły także na Andrzejowskiego w 1914 roku, kiedy to zesłano go do Astrachania. Przymusowa rozłąka z Kijowem zakończyła się dopiero po trzech latach, co po części było konsekwencją tego, że przez władze rosyjskie Andrzejowski postrzegany był jako niebezpieczny konspirator już na początku XX wieku. W Astrachaniu, położonym w delcie Wołgi, nie zaprzestał aktywnej działalności, czego potwierdzeniem może być niesiona przez niego pomoc znajdującym się tam licznym polskim zesłańcom. Szczególną opieką otaczał wysiedleńców z Polski. Z inspiracji Towarzystwa Pomocy Ofiarom Wojny zorganizował wspólnie z przewodniczącą Towarzystwa Dobroczynności - Stanisławą Klimaszewską, warsztat zajmujący się produkcją zabawek dziecinnych ${ }^{25}$.

Wydarzenia rewolucji marcowej 1917 roku umożliwiły Andrzejowskiemu powrót do Kijowa. W czerwcu tegoż roku powierzono mu pre-

23 Z. Andrzejowski, W Patagonii i na Dnieprze. Wspomnienia sprzed pół wieku, „PK” t. III, Londyn 1966, s. 230.

24 Prezesem Komitetu był Leonard Janowski, jeden z głównych ofiarodawców na rzecz kościoła, mecenas znacznej liczby polskich inicjatyw społeczno-kulturalnych, jak i stricte politycznych. Był m.in. jednym z głównych akcjonariuszy spółki wydającej „Dziennik Kijowski”.

25 J. Stemler, Życiorys, [w:] Pamiątka jubileuszu Józefata Andrzejowskiego..., s. $8-9$. 
zesurę w Macierzy Polskiej. Czynnie zaangażował się także w działalność Polskiego Komitetu Wykonawczego, w ramach którego kierował Wydziałem Oświaty. Warunki pracy oświatowej, pomimo upadku systemu carskiego, nie uległy wbrew oczekiwaniom szczególnej poprawie, wyzwoliły jednak w polskim społeczeństwie wyjątkową aktywność, stwarzając warunki do żywiołowego rozwoju polskiej oświaty ${ }^{26}$. I jak często wspominali jego uczestnicy, stanowił: „...najpiękniejszy okres rozwoju prac oświatowych na Rusi (...)"27. Nie trwał on jednak zbyt długo. Sytuacja polskiej oświaty pogarszała się z dnia na dzień, a było to spowodowane ciągłymi zmianami rządów na Ukrainie. Wrogie nastawienie do Polaków charakteryzowało zarówno Ukraińców, zwolenników armii Denikina, jak i bolszewików. Nie miało to jednak większego wpływu na kierunek prac Andrzejowskiego, uznającego służbę dla dobra sprawy polskiej na gruncie oświaty za rzecz najważniejszą, którą prowadzić należy w każdych, nawet najtrudniejszych warunkach.

Wieloletnia działalność społeczno-oświatowa Józefata Andrzejowskiego na Ukrainie znalazła żywe odzwierciedlenie w licznych wspomnieniach i pamiętnikach. Trudno wskazać obecnie relację odnoszącą się do polskiego życia w Kijowie i okolicach z przełomu XIX i XX wieku, która nie wspominała by jego nazwiska i dokonań. W krótkim wystąpieniu, mającym na celu przybliżenie sylwetki Andrzejowskiego, nie sposób przywołać wszystkich opinii na jego temat. Ograniczę się więc do kilku $\mathrm{z}$ nich, tym bardziej, że informacje zebrane w toku kwerend archiwalnych i bibliotecznych powtarzają się.

I tak dla Włodzimierza Bartoszewicza, syna redaktora „Dziennika Kijowskiego" Joachima Bartoszewicza, Andrzejowski był postacią wręcz charyzmatyczną. „Ktoś, kto by go nie znał - odnotował w spisanych w latach II wojny światowej wspomnieniach - a spojrzał na tego chuderlawego, niskiego staruszka o gładko przyczesanych siwiejących włosach i wąsach, kryjących dobrotliwy uśmiech, na tę twarz suchą o zgarbionym nosie i niebieskich oczach dziecka, uważnie spoglądających z pod brwi - nigdy by nie przypuścił, jaka siła moralna, jaka odwaga i stanowczość, jaki żar patriotyzmu i poświęcenia kryje się w sercu tego człowieka,

26 S. Sopicki, Omówienie pracy Jana Korneckiego „Oświata polska na Rusi w czasie Wielkiej Wojny Światowej”, „PK”, t. I, Londyn 1959, s. 200.

27 Jubileusz Józefata Andrzejowskiego, „Gazeta Warszawska” [dalej: „GW”], 15 VI 1929. 
bijącym pod szczelnie zapiętym popielatym surdutem”28. Według Bartoszewicza Andrzejowski był niemal symbolem służby narodowej na Kresach. Przez osoby blisko zaprzyjaźnione nazywały był „Ojcem Józefatem”. Godny przytoczenia wydaje się z cytowanych wspomnień także fragment dotyczący cech jego charakteru, w którym czytamy: „Skromny nad wyraz i cichy, zawsze przyjaźnie usposobiony i uśmiechnięty - stawał się groźny i surowy, gdy wypadło mu zetknąć się z podłością czy sprzeniewierzeniem się narodowym ideałom"29.

Przywołany już w artykule Konstanty Skrzyński napisał o Andrzejowskim, że był „....najbardziej zasłużoną i czcigodną postacią w życiu polskim na Rusi”30, a tym, co miało go wyróżniać spośród innych, była wręcz ojcowska dobrotliwość, którą młodzi członkowie „Polonii” mogli odczuć m.in. podczas prowadzonych przez niego spotkań ${ }^{31}$. Przytoczmy więc nieco dłuższy fragment jego wspomnień, stanowiący potwierdzenie tych słów, wzbogacający obraz jego sylwetki. „Ojciec Józefat był zawsze zapraszany do władz polskich organizacji na Rusi. Nigdy nie słyszałem, - podaje Skrzyński - żeby wygłosił dłuższe przemówienie. Ograniczały się one do spokojnego stwierdzenia: Ja panie dobrodzieju, niestety, na to się nie zgadzam", lub krótkie zgoda. Udział ojca Józefata w naszych zebraniach [mowa o spotkaniach członków i seniorów „Polonii” - dop. M.B.] nie był bierny. Kiedy zbieraliśmy się w jego domu z okazji jego imienin, to dostawaliśmy prawdziwy krupnik litewski i słuchaliśmy ze wzruszeniem, jak siadał do fortepianu i akompaniując sobie, śpiewał drżącym głosem: Francuzi myśmy dla was krew przelali. A wyście za to zdrada zapłacili..." ${ }^{\prime 2}$.

Andrzejowski w przeciwieństwie do wielu Polaków przez lata mieszkających i pracujących na Ukrainie, po zakończeniu wojny, a więc i odzyskaniu przez Polskę niepodległości, nie zdecydował się na wyjazd i osiedlenie w wolnej ojczyźnie. Kontynuował rozpoczętą przed czterdziestu laty pracy, pomimo że realia uległy całkowitej zmianie. Nowe bolszewickie rządy były bez porównania bardziej restrykcyjne i konsekwentne w tępieniu wszel-

28 Ossol., W. Bartoszewicz, Mój ojciec i jego czasy. Wspomnienia z lat 1867-1920, rkps 15611/II, k. 109.

29 Tamże.

30 Ossol., K. Skrzyński, Wspomnienia..., k. 71.

31 Tamże, k. 75.

32 Tamże, k. 90. 
kich przejawów działalności sprzecznej z ich interesami w porównaniu do władzy carskiej. Prowadzona przez Andrzejowskiego praca została potraktowana jako przejaw takiej właśnie wrogiej działalności, a on sam uznany za wroga ludu. Nadzieję na krótko przywrócił pochód wojsk polskich i zajęcie Kijowa w maju 1920 roku. Powszechnie znane koleje wojny polsko-bolszewickiej nie pozwalają zapomnieć, jak krótka była radość spowodowana bytnością wojsk polskich w grodzie nad Dnieprem. I tym razem Andrzejowski nie opuścił Kijowa, uznając, że dopóki ostatnie polskie dziecko z podległych mu szkół, ochronek i żłobków nie będzie bezpieczne i otoczone odpowiednią opieką, on sam jest ostatnią osobą, która może myśleć o wyjeździe do Polski.

Działając w ekstremalnie trudnych warunkach, ukrywając się przed bolszewickim reżimem, podjął pracę jako robotnik w zakładach pod Kijowem. Sowiecką Ukrainę opuścił ostatecznie dopiero po traktacie ryskim. Powrót do Polski w październiku 1921 roku został na nim wręcz wymuszony przez przyjaciół i przywódców Narodowej Demokracji ${ }^{33}$. Do kraju przywiózł grupę polskich dzieci z Kijowa i okolic ${ }^{34}$. Wydarzenie to opisał m.in. Jan Kornecki w rozprawie o polskich pracach oświatowych na Ukrainie w latach 1914-1918. „Sędziwy starzec wytrwał na stanowisku najdłużej - pisał Kornecki - ukrywając się prawie przez dwa lata (1920-1921) przed agentami czerezwyczajki bolszewickiej o głodzie i chłodzie; pracując chwilami jako zwykły robotnik, czuwał nad funkcjonującymi jeszcze szkołami kijowskimi i podtrzymywał na duchu opadające z sił nauczycielstwo. Dopiero w jesieni 1921 roku przyjechał do Kraju, nie sam jeden, ale z 93 wychowankami szkół kijowskich. Przyjechał po to by organizować pomoc dla pozostałej pod rządami bolszewickimi młodzieży, której los był coraz cięższy"35.

Udostępnione w ostatnich latach materiały z przesłuchań współpracującej w tym okresie z Józefatem Andrzejowskim Marii Szumowicz, przeprowadzonych na początku 1931 roku przez funkcjonariuszy OGPU, jednoznacznie wskazują, z jak wielkim poświęceniem działał pomimo grożącego mu stale niebezpieczeństwa. „Rząd polski nie chciał stracić swych wpływów w Kijowie - czytamy w protokole zeznania Szumowicz

33 B PAU i PAN w Krakowie, J. Kornecki, Pamiętniki, k. 206.

34 Wsparcia w tym skomplikowanym i trudnym zadaniu udzielili mu m.in.: Maria Stępowska i Bolesław Guttman.

35 Cyt. za: S. Sopicki, Omówienie..., s. 204. 
z dnia 21 stycznia 1931 roku - dlatego też zwracano szczególną uwagę na problemy wychowania dorastającego młodego pokolenia. Szczególny wpływ na ów proces miało duchowieństwo, głównie za sprawą ks. Skalskiego, jak również pośrednio niektórych pedagogów szkolnych. (...) Oprócz Skalskiego aktywnie działał na tym polu także ukrywający się w Kijowie były przewodniczący Komitetu Wykonawczego Andrzejowski, którego osobiście nie znałam. Złożył mi jednak wizytę, długo rozmawialiśmy o organizującej się wtedy szkole, wiele mówił o konieczności włączenia do organizującej się szkoły dzieci rodzin, które nie zdążyły wyjechać do Polski. Odchodząc pobłogosławił mnie „na ciernistą drogę walki z bolszewikami i zachowania prężnej polskiej szkoły”. Swoje wytyczne obiecał przekazywać przez Bolesława Gutmana, który pomagał mu się ukrywać, i który był w tym czasie instruktorem polskich szkół oraz dyrektorem męskiej szkoły przy Zaułku Rylskim"36.

W wolnej Polsce, pomimo przekroczonych już siedemdziesięciu lat życia, włączył się wir działalności społeczno-oświatowej. Pracował w Polskiej Macierzy Szkolnej, działał w Polskim Czerwonym Krzyżu. Ze szczególną atencją śledził losy polskiej młodzieży z Kresów, której niejednokrotnie w bardzo trudnych warunkach przyszło egzystować w niepodległej Polsce. Dla tej właśnie młodzieży stworzył dwie bursy studenckie. Jedna $\mathrm{z}$ nich w uznaniu zasług została nazwana jego imieniem. Do tych działań po części obligowały go obowiązki wynikające $\mathrm{z}$ faktu, że był nominalnie ostatnim prezesem Polskiego Komitetu Wykonawczego.

W uznaniu zasług, które położył na polu krzewienia polskiej oświa-

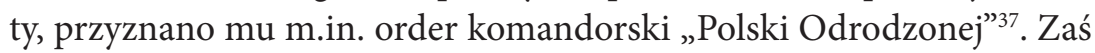
Polska Macierz Szkolna nadała mu najwyższą godność, tj. członka honorowego. Środowisko przedwojennych kijowskich współpracowników, których duża grupa osiedliła się w Polsce, głównie w Warszawie, zorganizowała Andrzejowskiemu w dniu 16 czerwca 1929 r. uroczysty jubileusz osiemdziesiątych urodzin i sześćdziesięciolecia pracy na gruncie społeczno-oświatowym ${ }^{38}$. W imprezie, która odbyła się w warszawskiej

36 http://www.pwin.c-net.pl/ Patrz: zakładka badania, dokument nr 9.

37 BN, D. Szarzyński-Sęp, Polskie..., k. 81.

38 W skład Komitetu Jubileuszowego weszły łącznie 44 osoby - także ci, którym przyszło z Andrzejowskim zetknąć się dopiero po jego przybyciu do Polski w $1921 \mathrm{r}$. 
Resursie Obywatelskiej, uczestniczyło kilkadziesiąt osób. Trwałą po niej pozostałością, oprócz licznych artykułów prasowych, była okolicznościowa publikacja, będącą współcześnie jednym z cenniejszych źródeł, służących historykowi do poznania biografii Józefata Andrzejowskiego. Pracę otwiera dedykacja, w której czytamy: „Niestrudzonemu pracownikowi na niwie odrodzenia narodowego, orędownikowi sprawy bożej na ziemi, nestorowi i kierownikowi prac oświatowych w okresie niewoli i w odrodzonej Polsce, Józefatowi Andrzejowskiemu"39. W pracy tej pomieszczone zostały wystąpienia, które 16 czerwca 1929 roku wygłoszono na jego cześć. $Z$ uwagi na to, że większość z nich była zbliżona w swojej wymowie, przywołajmy w tym miejscu jeden z fragmentów przemówienia Joachim Bartoszewicza, które otwierało serię wystąpień na cześć jubilata ${ }^{40}$. Dla Bartoszewicza Andrzejowski to człowiek, który rozpoczynając prace na dalekich kresach, „nie mędrkował, nie zniechęcał się tym, co przeczuwał, że zobaczy, ale wiedział, że jako Polak, ma czynić dobrze dla Polski" ${ }^{11}$. Andrzejowski w jego ocenie to przede wszystkim człowiek wierzący w potęgę ducha polskiego na kresach, który to jednak wydobyć można było tylko dzięki wytrwałej pracy. Najlepsze jej efekty dla ducha polskiego, jak podkreślał Bartoszewicz, Józefat Andrzejowski dostrzegał w korzyściach płynących z pracy oświatowej, a jej powodzenie było zdeterminowane tym, że kierowała nim konieczność działania. Andrzejowski miał jego zdaniem nie stawiać sobie nigdy pytania, czy warto, czy jest sens działać w tak trudnych warunkach ${ }^{42}$.

Józefat Andrzejowski zmarł w Warszawie tuż po wybuchu II wojny światowej przeżywszy 92 lata. W ostatniej drodze 6 października 1939 roku towarzyszyło mu grono najbliższych przyjaciół i współpracowników $^{43}$. Pochowany został na Cmentarzu Brudnowskim ${ }^{44}$. Dla wielu wraz z jego odejściem kończył się bardzo ważny rozdział pracy na rzecz

39 J. Stemler, Życiorys, [w:] Pamiątka jubileuszu Józefata Andrzejowskiego..., s. 3.

40 Więcej na temat biografii Joachima Bartoszewicza zob.: M. Białokur, Myśl społeczno-polityczna Joachima Bartoszewicza, Toruń 2005, s. 21-128.

41 Przemówienie Joachima Bartoszewicza, [w:] Pamiątka jubileuszu Józefata Andrzejowskiego..., s. 15.

42 Tamże, s. 16.

43 B PAU i PAN w Krakowie, J. Kornecki, Pamiętniki, k. 206.

44 BN, D. Szarzyński-Sęp, Polskie..., k. 81. 
polskiej oświaty. W latach II wojny światowej, kiedy okupanci podjęli próbę zagłady narodu polskiego m.in. poprzez zniszczenie jego oświaty, pamięć o heroicznej postawie Andrzejowskiego na polu działalności oświatowej miała wymiar symboliczny ${ }^{45}$. Wieloletnia działalność Józefata Andrzejowskiego na niwie pracy oświatowo-wychowawczej na Ukrainie wskazuje, iż jego prawdziwą polską rodziną na Wschodzie były tysiące polskich dzieci, którym tworzył warunki do nauki lub też ratował spod jarzma bolszewickiej zarazy. Ten ogromny wysiłek, jak pokazały liczne cytaty przywołane w tekście oraz okazały jubileusz zorganizowany mu przez uczniów i współpracowników w osiemdziesiątą rocznicę urodzin, utrwalił się w sercach i pamięci jemu współczesnych. Warto jednak, aby także dzisiaj, kiedy od czasów aktywnej działalności Józefata Andrzejowskiego upływa już niemal całe stulecie, pamięć o nim oraz wielu tysiącach innych polskich działaczy oświatowo-wychowawczych wspierających polskie rodziny na Wschodzie nie została odsunięta do lamusa. Jesteśmy to winni im wszystkim jako przedstawiciele narodu, który zachował swą godność, tożsamość, język, religię i kulturę, bo oni mieli odwagę stale nam o tym przypominać, stwarzając jednocześnie warunki ku ich zachowaniu i kultywowaniu. Kończąc, przywołajmy jeszcze jedną z wielu publicznych wypowiedzi, której bohaterem był Józefa Andrzejowski, nestor polskiej rodziny na Wschodzie. „Miarą ludzi wielkich jest ich nieporównywalność. Człowieka, który nad otoczeniem góruje, nie można określić pojęciami, stworzonymi do określenia jednostek z otoczenia. Człowiek wielki dlatego jest wielkim, że ma w pewnej dziedzinie wyłączność, monopol, czy to wiedzy, czy odwagi, czy pieniędzy, czy charakteru. Ta jest tylko nieścisłość $\mathrm{w}$ analogii z monopolem, że prawdziwa wielkość nie daje zwykle wielkim nic, on zaś oddaje innym wszystko, co zdobył, więc - zdobywa po to, aby innym oddać. Monopolistą takim, monopolistą wielkim, monopolistą ducha, monopolistą charakteru jest Pan Józefat Andrzejowski" ${ }^{36}$.

45 Ossol., W. Bartoszewicz, Mój ojciec..., k. 110.

46 Przemówienie Jerzego Kurcyusza, [w:] Pamiątka jubileuszu Józefata Andrzejowskiego..., s. 19-20. 


\section{Bibliografia}

\section{Zbiory rękopiśmienne:}

Biblioteka Polskiej Akademii Umiejętności i Polskiej Akademii Nauk w Krakowie, Teki Zielińskiego: Jan Kornecki, Pamiętniki, mf. 1476.

Biblioteka Narodowa, D. Szarzyński-Sęp, Polskie Towarzystwo Oświaty Ludowej na Rusi. Szkice i przyczynki do dziejów oświaty polskiej na Rusi w latach 1870-1920, akc. 8747.

Biblioteka Zakładu Narodowego im. Ossolińskich we Wrocławiu

- S. Zieliński, Liga Narodowa na Rusi 1890-1920. Fragmenty historii pracy polskiej na kresach południowo-wschodnich, rkps 13202/II.

- K. Skrzyński, Wspomnienia z lat 1891-1917, rkps 15585/II.

- W. Bartoszewicz, Mój ojciec i jego czasy. Wspomnienia z lat 1867-1920, rkps 15611/II.

\section{Literatura i prasa:}

Andrzejowski Z., W Patagonii i na Dnieprze. Wspomnienia sprzed pół wieku, „Pamiętnik Kijowski”, t. III, Londyn 1966.

Beauvois D., Rosyjsko-polska wojna o oświatę na terenie Ukrainy (1863-1914), [w:] Europa Nie prowincjonalna. Przemiany na ziemiach wschodnich dawnej Rzeczypospolitej. Białoruś, Litwa, Ukraina, wschodnie pogranicze III Rzeczypospolitej Polskiej w latach 1772-1999, red. K. Jasiewicz, Warszawa 1999.

Beauvois D., Trójkąt ukraiński. Szlachta, carat i lud na Wołyniu, Podolu i Kijowszczyźnie 1793-1914, Lublin 2005.

Białokur M., Myśl społeczno-polityczna Joachima Bartoszewicza, Toruń 2005.

Białokur M., Powstanie i pierwsze lata działalności Towarzystwa Oświaty Narodowej na Rusi (1904-1909), [w:] Dzieje kształtowania się polskich instytucji oświatowych, red. A. Mierzwa, Piotrków Trybunalski 2002.

Eberhardt P., Polska ludność kresowa. Rodowód, liczebność, rozmieszczenie, Warszawa 1998.

Józefatowi Andrzejowskiemu w hołdzie, „Myśl Narodowa”, nr 25 z 16 VI 1929.

Kozicki S., Historia Ligi Narodowej. (Okres 1887-1907), Londyn 1964.

Kto był kim w Drugiej Rzeczypospolitej, red. J.M. Majchrowski, Warszawa 1994.

Olizar B., Liga Narodowa, „Pamiętnik Kijowski”, t. III, Londyn 1966.

Oświata polska na Rusi: S. Zieliński, Przedmowa do pracy Jana Korneckiego „Oświata polska na Rusi w czasie Wielkiej Wojny Światowej”, „Pamiętnik Kijowski”, t. I, Londyn 1959.

Pamiątka jubileuszu Józefata Andrzejowskiego uczczonego obchodem uroczystym 16 czerwca 1929 roku, Warszawa 1930. 
Sopicki S., Omówienie pracy Jana Korneckiego „Oświata polska na Rusi w czasie Wielkiej Wojny Światowej”, „Pamiętnik Kijowski”, t. I, Londyn 1959.

Wielhorski W., Ziemie ukrainne Rzeczypospolitej. Zarys dziejów, „Pamiętnik Kijowski”, t. I, Londyn 1959.

Wierzejewski W.K., Fragmenty $z$ dziejów polskiej młodzieży akademickiej w Kijowie 1834-1920, Warszawa 1939.

Wolsza T., Narodowa Demokracja wobec chłopów w latach 1887-1914. Programy, polityka, działalność, Warszawa 1992.

Wolsza T., Towarzystwo Oświaty Narodowej (1899-1905), „Kwartalnik Historyczny", 2 (1987).

Żmichrowska M.J., Jan Kornecki (1884-1967). Działalność oświatowa, społeczna, polityczna, Warszawa 1996.

\section{Netografia:}

http://powstaniec1863.zsi.kielce.pl/index.php?id=m10.

http://www.pwin.c-net.pl/ Patrz: zakładka badania, dokument nr 9. 


\section{C.A.S. \\ CENTRUM ANALZ
STRATEGICZNYCH}

W OPOLU

\section{Centrum Analiz Strategicznych Collegium Nobilium Opoliense}

W 2019 roku dziatalność rozpoczęto Centrum Analiz Strategicznych Collegium Nobilium Opoliense. Jest to niezależna instytucja doradcza zajmująca się analizami dotyczącymi spraw publicznych. Celem Centrum jest opracowanie kompleksowych rozwiązań problemów spotecznych istotnych dla województwa opolskiego. W ramach prowadzonej dziatalności wydajemy raporty i opinie na temat m.in. poziomu dobrostanu i jakości życia, rozwoju spoteczeństwa obywatelskiego, nauki i szkolnictwa wyższego, mediów, samorządu i polityki wewnętrznej Polski. Nasz zespót składa się doświadczonych specjalistów. Eksperci Centrum Analiz Strategicznych CNO to naukowcy i praktycy z wieloletnim stażem w uczelniach polskich i zagranicznych, administracji, organizacjach pozarządowych i sektorze prywatnym.

Kontakt: Centrum Analiz Strategicznych CNO, ul. Ozimska 36/1, 45-058 Opole, opole.cas@gmail.com 


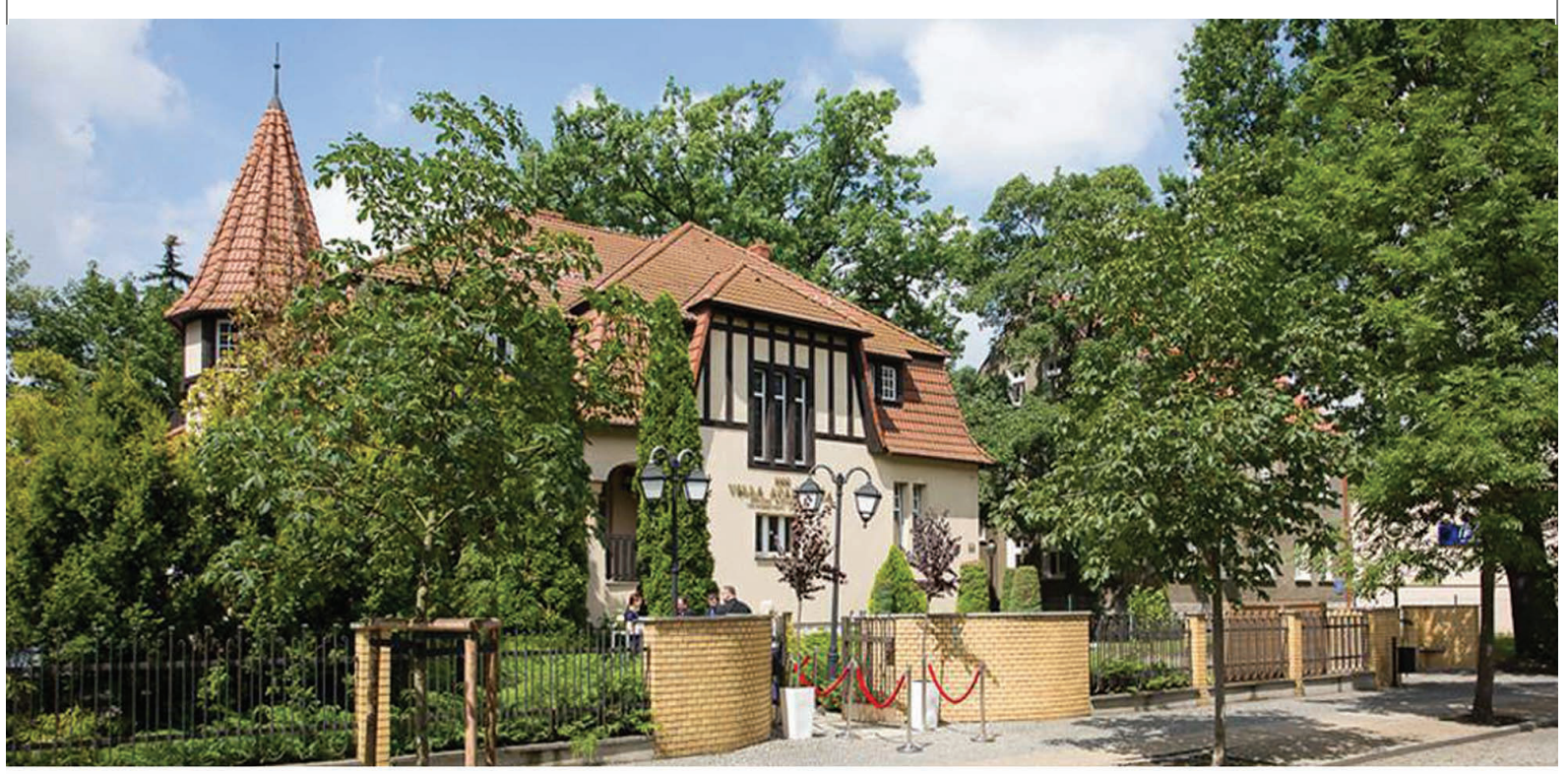

\section{Regionalny Ośrodek Debaty Międzynarodowej w Opolu}

Celem działalności RODM Opole jest przybliżenie obywatelom polskiej polityki zagranicznej oraz wzmocnienie kanałów współpracy pomiędzy MSZ, jednostkami samorządu terytorialnego, organizacjami pozarządowymi, placówkami edukacyjnymi i naukowymi oraz innymi podmiotami, których działalność obejmuje szeroko rozumianą współpracę międzynarodową.

Cel ten realizowany jest poprzez:

- animowanie i inicjowanie w regionie działań z zakresu współpracy międzynarodowej;

- koordynowanie inicjatyw podejmowanych w regionach przez instytucje publiczne i organizacje pozarządowe z zakresu polityki zagranicznej;

- gromadzenie materiałów, baz danych, opracowań z tego zakresu;
- zbieranie i aktualizowanie informacji o podmiotach realizujących $\mathrm{w}$ regionach działania $\mathrm{z}$ zakresu polityki zagranicznej;

- prowadzenia działalności informacyjnej i edukacyjnej dla społeczności regionu w kwestiach dotyczących UE i polskiej polityki zagranicznej;

- prowadzenie ośrodka, w którym będą udostępniane materiały, opracowania i publikacje o tematyce związanej z polską polityką zagraniczną, a konsultanci będą udzielać informacji na tematy związane z polską polityką zagraniczną, w tym dotyczące funkcjonowania Unii Europejskiej oraz członkostwa Polski w UE.

Organizacją prowadzącą Regionalny Ośrodek Debaty Międzynarodowej w Opolu jest Fundacja Collegium Nobilium Opoliense.

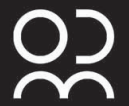

Ośrodek Debaty Międzynarodowej Opole ul. Powstańców Śląskich 22

45-069 Opole

tel. 530735865

www.rodm-opole.pl www.facebook.com/RODMOpole
Zadanie dofinansowane ze środków

Ministerstwa Spraw Zagranicznych 


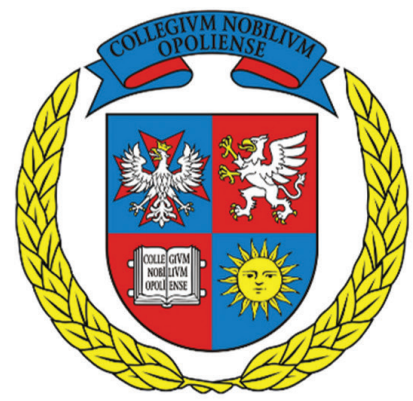

\section{Collegium Nobilium Opoliense}

Misja: W oparciu o konserwatywne wartości kształcić za pomocą najnowocześniejszych metod nowe elity, zdolne podejmować wyzwania globalne na miarę XXI w.

Collegium Nobilium Opoliense to szkoła - kuźnia idei i charakterów w duchu patriotyzmu wyrażanego szacunkiem do państwa, jego tradycji i historii, pracowitością i oddaniem dla dobra wspólnego, budową dobrobytu w oparciu o wolny rynek i przedsiębiorczość obywateli, troską o sytuację rodziny i odbudowę etosu zaangażowania i służby publicznej.

Collegium Nobilium Opoliense to wyjątkowe miejsce spotkań elit: tych przyszłych z obecnymi. Jest to płaszczyzna wymiany myśli i doświadczeń, gdzie młodzi ludzie mogą korzystać z wiedzy autorytetów. Środowisko Collegium tworzą ludzie zaangażowani, nieobojętni na procesy zachodzące w świecie. Dzięki wytrwałości i konsekwencji kadry Collegium, stało się ono jedyną taką wspólnotą w kraju. Kształcimy nowe elity i integrujemy te, które obecnie kształtują rzeczywistość. W tym roku rozpoczęła się już IX edycja tej unikatowej szkoły liderów.

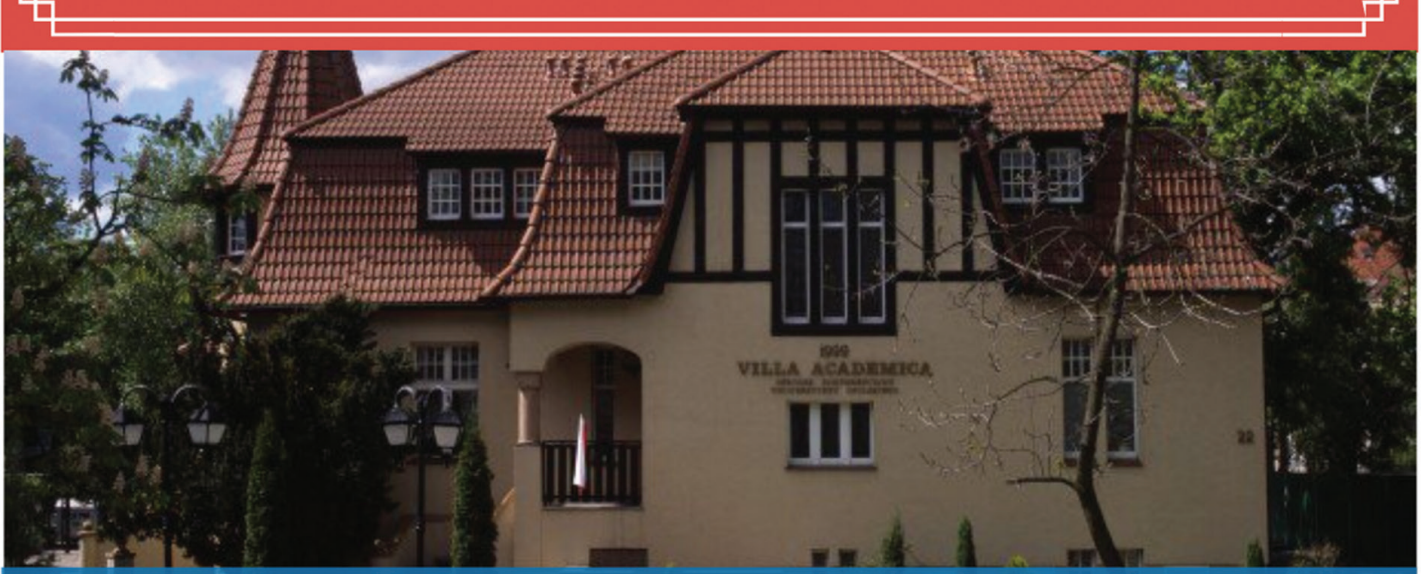

Siedziba szkoły mieści się w Opolu przy ul. Powstańców Śląskich 22, w Villa Academica. 


\section{Stowarzyszenie Ludzi Aktywnych Horyzonty}

Misja: Budujemy społeczeństwo obywatelskie.

Stowarzyszenie Ludzi Aktywnych Horyzonty jest organizacją ludzi ambitnych i nieobojętnych na otaczającą rzeczywistość. Obserwując świat chcemy mieć na niego wpływ, pragniemy go zmieniać. Stawiamy sobie ambitne cele, łamiemy schematy i stereotypy. Horyzonty skupiają ludzi o różnych charakterach i zainteresowaniach, ale łączy nas idea silnej i nowoczesnej Polski. Pracujemy na rzecz społeczeństwa obywatelskiego na polu kulturalnym, charytatywnym, naukowym, samorządowym, politycznym oraz edukacyjnym.

Stowarzyszenie Ludzi Aktywnych Horyzonty jest organizacją pożytku publicznego. Nr KRS: 0000250396
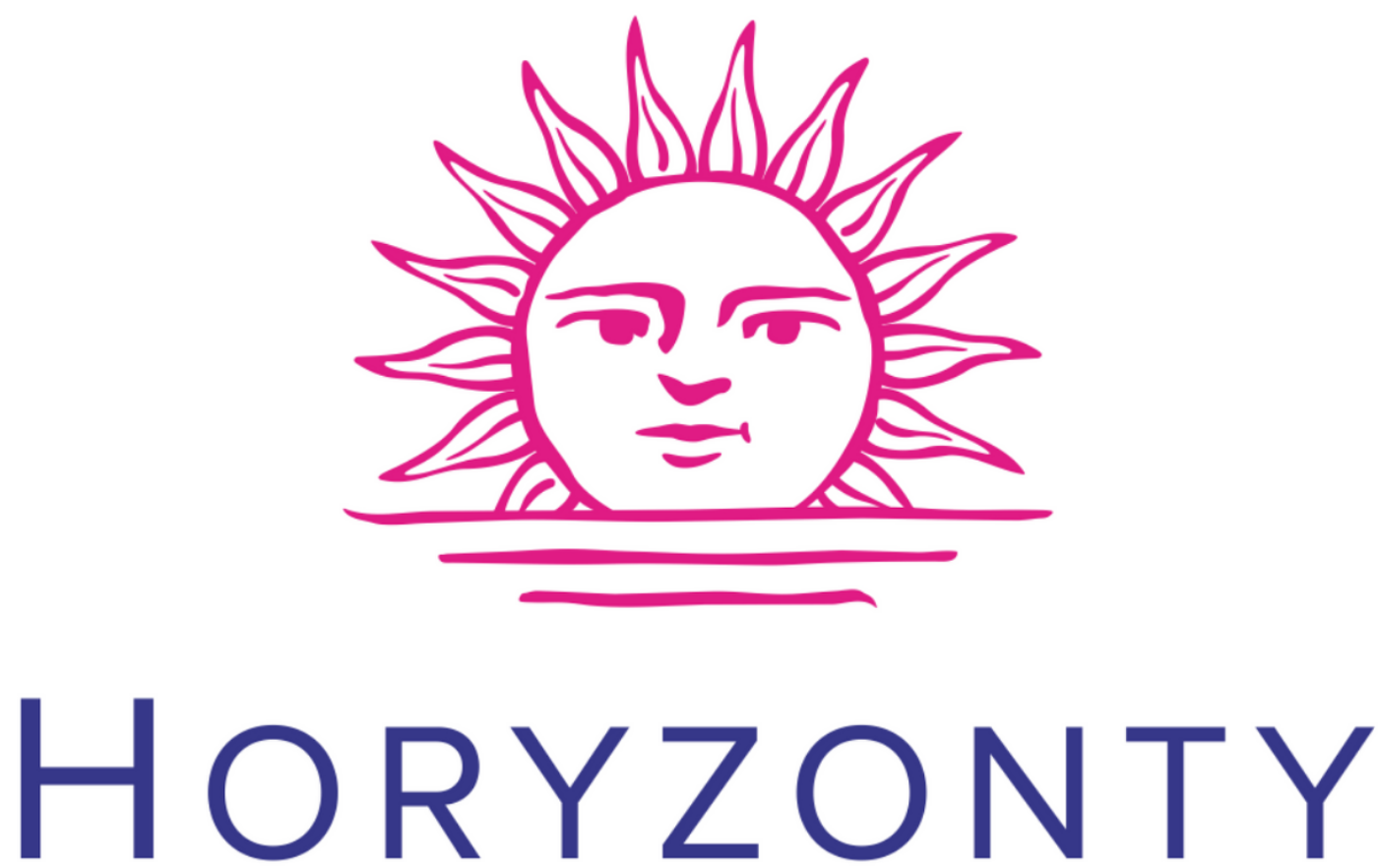

STOWARZYSZENIE LUDZI AKTYWNYCH 